\title{
Effects of eutrophication on salt marsh root and rhizome biomass accumulation
}

\author{
Faith A. Darby, R. Eugene Turner* \\ Department of Oceanography and Coastal Sciences, Louisiana State University, Baton Rouge, Louisiana 70803, USA
}

\begin{abstract}
The root:shoot ratio of grassland plants may be lower in high fertility sites than in low fertility sites as plants modify their root, rhizome and shoot morphologies (and masses) to suit prevailing nutrient availability. We conducted geographically diverse and regionally specific field sampling and measured above- and belowground plant biomasses in western Atlantic and Gulf of Mexico salt marshes to determine whether there is a similar morphological response in Spartina alterniflora, the dominant salt marsh plant. Coastal nutrient addition/enrichment, which is widespread and ongoing, may lower root and rhizome biomass, belowground production and organic accumulation in this species. Higher soil respiration and a lower Eh (redox potential) are expected additional soil property changes. The addition of $\mathrm{P}$, more than of $\mathrm{N}$, seems to reduce root and rhizome biomass accumulation. The cumulative effects of increased nutrient loadings on salt marshes may be to decrease soil elevation and accelerate the conversion of emergent plant habitat to open water, particularly on the lower marsh. The recommendations for management practices intended to conserve coastal marshes include reducing nutrient loading to coastal zones, solving water quality problems with a multiple nutrient approach, and choosing monitoring metrics that are based on both above- and belowground plant biomass.
\end{abstract}

KEY WORDS: Salt marsh · Nutrients $\cdot$ Spartina alterniflora $\cdot$ Belowground biomass $\cdot$ Die-back Resale or republication not permitted without written consent of the publisher

\section{INTRODUCTION}

Nutrient supply is generally accepted as a determinant of plant composition, growth and productivity (Chapin 1980). Plants may adjust their nutrient foraging capacity by modifying root, rhizome and shoot morphology, and mass (Gedroc el al. 1996). Grassland plants, for example, develop lower root: shoot biomass ratios as soil fertility increases and aboveground production rises (Tilman \& Wedin 1991). A similar decline in the root:shoot ratio may also occur in coastal marshes under the influence of anthropogenic nutrient enrichment, and thus affect the soil ecosystem. Valiela et al. (1976), for example, documented stimulation of aboveground production and a reduced root + rhizome biomass under different experimental additions of $\mathrm{N}+$ $\mathrm{P}$ applied to tidally-flooded organic-rich salt marshes in Massachusetts, USA. Valiela et al. (1976) were among the first to quantify some of the connections between marsh survival, nutrient loading, and belowground plant production. We continued these investigations.

Coastal salt marshes maintain their vertical position within the upper portion of the local tidal range through the accumulation of both inorganic and organic materials. The long-term health of an organicrich salt marsh is dependent on the amount and fate of this belowground organic production. In organic-rich salt marshes, soil density is primarily determined by the inorganic content, and the accretion rate is determined by the vertical accumulation of organics (Gosselink et al. 1984, Turner et al. 2000). Differences between streamside and inland organic accumulation in a Virginia (USA) marsh, for example, are explained by variations in the organic production belowground rather than variations in the decomposition rates or inorganic content (Blum 1993). A coastal marsh may convert to open water or upland vegetation if organic 
accretion is too low or too high, respectively. An aggressive new form of Phragmites australis apparently out-competes Spartina alterniflora on the landward side of cordgrass distribution; in part, the dominance of $P$. australis results from its greater belowground biomass production, with a consequent rise in soil elevation that has negative effects on $S$. alterniflora (Rooth \& Stevenson 2000, Bertness et al. 2002). Soil elevation may be lowered to the detriment of cordgrass survival if either root production is decreased or the decomposition of accumulated organic matter is accelerated sufficiently that net organic accumulation is less than relative sea level rise. Additional evidence for the influence of belowground biomass on marsh vigor is that the amount of live root + rhizome $(\mathrm{R}+\mathrm{R})$ biomass is a diagnostic of plant health in Louisiana salt marshes (Turner et al. 2004). The $R+R$ biomass there was 7 times higher in marshes categorized as 'healthy' than in deteriorating 'unhealthy' marshes.

An implication of these observations is that the increase in nutrient loading to coastal systems, which are widespread (National Research Council 2000, Cloern 2001, Rabalais 2002, Howarth \& Marino 2006), may alter marsh ecosystem functions and perhaps compromise the long-term stability of salt marshes by reducing root production and causing a consequential decline in soil organic accumulation. Morris \& Bradley (1999), for example, found that, compared to unfertilized sites in a South Carolina salt marsh, fertilization for $12 \mathrm{yr}$ increased soil respiration by $36 \%$ and decreased soil carbon accumulation by $40 \mathrm{~g} \mathrm{C} \mathrm{m}^{2} \mathrm{yr}^{-1}$. They found a rise in surface elevation, however, because of the compensatory accumulation of inorganic material in this relatively mineral-rich marsh, something that is less likely in organic-rich sediments. The effects of higher nutrient loading on soil organics would not be expressed equally along a latitudinal gradient or within the tidal range occupied, however, because of the varying effects of climate and flooding on sulfide accumulation, soil respiration, root physiology, and soil quality. Temperature, for example, has a well-established direct effect on soil organic decomposition and root turnover (Gill \& Jackson 2000), and salt marsh plants have some physiological abilities to adapt to flooding and salt stress (Mendelssohn et al. 1981, King et al. 1982). Also, the hydrologic regime - which is reflected in soil porosity, wetness, and cation exchange capacity - influences the long-term distribution of sediment quality and quantity.

We report here on a combination of geographically diverse and regionally-specific sampling of belowground biomass under various nutrient addition experiments designed to investigate the effects of nutrient loading on salt marsh ecosystems dominated by
Spartina alterniflora. We conducted these experiments in western Atlantic and Gulf of Mexico (GOM) salt marshes using a springtime addition of $\mathrm{N}$ and/or $\mathrm{P}$, and monthly additions of N, P and Fe in a Louisiana (USA) salt marsh. The results from the end-of-summer sampling are discussed here.

\section{MATERIALS AND METHODS}

Monospecific stands of Spartina alterniflora were sampled at locations at least $10 \mathrm{~m}$ away from a streamside marsh. All of the marshes were in eastern North America. There were 2 locations at Cocodrie, Louisiana (LA-C), 3 at Empire, Louisiana (LA-E), 1 at Sapelo Island, Georgia (GA), 2 at the Upper Phillips Creek Marsh within the Virginia Coast Reserve, Virginia (VA), 2 at the Great Sippewisset marsh, Falmouth, Massachusetts (MA), and 1 at Windsor Causeway, Nova Scotia, Canada (NS). Descriptions of these marshes are in Darby \& Turner (2008a; LA-C), Spicer (2007; LA-E), Schuhauer \& Hopkinson (1984; GA), Blum (1993, Blum \& Christian 1995; VA), Valiela et al. (1976; MA), and Daborn et al. (2003; NS).

The sampling design consisted of replicate $0.5 \times$ $0.5 \mathrm{~m}$ plots designated as control or fertilized plots. The individual plots were separated by at least $0.5 \mathrm{~m}$ and the combined set of control and fertilized plots are designated as a treatment site. The 3 LA-E, 1 LA-C, 2 VA, and 2 MA treatment sites were fertilized in May 2005 and sampled in September 2005. The single plot fertilizer dosage was 2246 and $66 \mathrm{~kg} \mathrm{ha}^{-1} \mathrm{~N}$ and $\mathrm{P}$, respectively, as ammonium sulfate $(33 \%)$ and superphosphate $(18 \%)$. All treatments included duplicate control, and N+P plots. The VA and MA plots also had duplicate $+\mathrm{P}$ plots at each treatment site. The NS marsh was fertilized in May 2006 with Osmocote@ slow-release fertilizer that released 174 and $46 \mathrm{~kg} \mathrm{ha}^{-1}$ of $\mathrm{N}$ and $\mathrm{P}$, respectively; this marsh was sampled the following September. Some data on the below- and aboveground biomass from plots treated with 12 different combinations of $\mathrm{N}$ (ammonium sulfate), $\mathrm{P}$ (superphoshate) and Fe (Ironite) ( $\mathrm{n}=3$ plots per treatment) additions to an LA-C salt marsh are described by Darby \& Turner (2008b), and included here. The nutrient loading rates applied in this analysis are within the range of $\mathrm{N}$ and $\mathrm{P}$ loadings to GOM estuaries (Turner \& Rabalais 1999) and are comparable to those of others (Valiela et al. 1976, Mendelssohn 1979, Morris \& Bradley 1999, Huang \& Morris 2005).

Spartina alterniflora was harvested by clipping vegetation at the sediment surface. All standing live and dead culms and litter were removed from the control and fertilized plots and placed into pre-labeled plastic bags and transported to the Louisiana State University 
(LSU) processing laboratory. Dead shoots and leaves were identified by their yellowish or brownish coloration and separated from living material. The live or dead plant material was put into pre-labeled paper bags, dried at $75^{\circ} \mathrm{C}$ for approximately $72 \mathrm{~h}$, and weighed to the nearest $0.1 \mathrm{~g}$.

Belowground biomass was collected using a $40 \mathrm{~cm}$ long stainless steel tube with a sharpened edge. An $11 \mathrm{~cm}$ diameter by $30 \mathrm{~cm}$ long sediment core was taken in the middle of each plot after the aboveground biomass sample was collected. The cores were extruded in the field and sliced into $0-10 \mathrm{~cm}, 10-20 \mathrm{~cm}$ and 20-30 cm segments, each segment was placed in labeled plastic Ziplocs ${ }^{\circledR}$ bags, and then transported in a cooler to the LSU laboratory where they were refrigerated until processed. Each segment was washed in a $1 \mathrm{~mm}$ sieve over a $0.5 \mathrm{~mm}$ sieve to prevent the loss of dead and fine root material. Live roots and rhizomes were separated from dead material with a suture set under running water for better separation (live roots and rhizomes are white and turgid; dead materials are dark and flaccid). Root color can be variously tinged pink or orange, possibly because of pigmentation zones, e.g. roots colonized by arbuscular mycorrhizal fungi are often yellow (authors' pers. obs.). The physiological significance of these pigments is unclear (Alistair et al. 2002). Discolored turgid roots were defined as live roots. Dead material included partially decayed root material. Cores containing a large amount of rocks, shell, and miscellaneous debris were placed in water and sorted with a small kitchen strainer. Live and dead roots floated, and rocks, etc. sank. Live roots and dead belowground material were placed in paper bags, labeled, and dried at $60^{\circ} \mathrm{C}$ for to $72 \mathrm{~h}$, then weighed to the nearest $0.01 \mathrm{~g}$.

The results for August from the low- and high fertilizer addition experiments in a Massachusetts salt marsh (Valiela et al. 1976) were included in our comparison. Valiela et al.'s (1976) low fertilizer treatment in the 'low marsh' was discarded because, as will be shown, the datum point was an outlier among all others. The results from their (op. cit.) fertilization experiment using urea as a nitrogen source were not included because no other experiments used urea as a nitrogen source. The Valiela et al. (1976) 1975 data set is not presented in a way that allows calculation of a standard error (SE) for roots + rhizome biomass. Rhizome biomass is about $3 \times$ greater than root biomass (see our 'Results: Above- and belowground biomass'), and the SE for the rhizomes could be calculated by estimating the rhizome biomass in their figures. We used the estimated SE of the rhizome biomass as a surrogate for live belowground biomass in control and experimental plots. The SE for the aboveground biomass was estimated from the SE bars in their (op. cit.) figures. The SE for the above- and belowground biomass for these data represents the within site variance for a single plot. The SE data from our experiments at the MA, VA, LA-E and LA-C marshes are for the average of replicates within one experimental treatment, and therefore represents the among-plot variance. The information on SE was converted to \% change relative to the below- and aboveground live biomass in the control plots.

The results of a statistical analysis of belowground biomass at our experimental sites where $\mathrm{N}$ or $\mathrm{N}+\mathrm{P}$ were applied were compared to determine whether there were pairwise significant differences between means ( $p<0.05$, Tukey's test). The analysis was carried out using the general linear model procedure (ANOVA; SAS Institute 2003).

We measured soil Eh at $10 \mathrm{~cm}$ depth for a salt marsh at Cocodrie, LA where standing stocks of live belowand aboveground biomass were manipulated by monthly additions of various combinations of N, P, and Fe in a triplicated experiment (Darby \& Turner 2008b). The dosage consisted of a factorial design of various combinations of 22 and $60 \mathrm{~kg} \mathrm{ha}^{-1} \mathrm{yr}^{-1}$ of $\mathrm{P}$ and $\mathrm{Fe}$, respectively, and five different doses of $\mathrm{N}(\mathrm{N} 1, \mathrm{~N} 2, \mathrm{~N} 3$, $\mathrm{N} 4$, N5) ranging between 0 and $3720 \mathrm{~kg} \mathrm{ha}^{-1} \mathrm{yr}^{-1}$, in a total of 36 plots. Soil Eh was measured at $10 \mathrm{~cm}$ depth using three Eh probes (brightened platinum) calibrated in the laboratory before and after the field trip. Eh was measured using a digital voltmeter as the potential $(\mathrm{mV})$ of a calomel electrode against the Eh probe. The half-potential of the calomel electrode $(+244 \mathrm{mV})$ was added to the measured potential to calculate Eh. The plant harvest and Eh measurements at Cocodrie, LA took place on 3 September 2004 when the aboveground live biomass was at a seasonal maximum.

\section{RESULTS}

\section{Above- and belowground biomass}

In response to a combination of nitrogen and phosphorus fertilizer added to the surface of 11 salt marshes in Nova Scotia, Massachusetts, Virginia, and Louisiana and from 3 fertilized sites studied by Valiela et al. (1976), plants increased aboveground live biomass by an average of $169 \pm 40 \%$ (mean $\pm \mathrm{SD}, \mathrm{n}=14$ ) of the value at the unfertilized control sites (Fig. 1). This aboveground response was consistent with the results from $>12$ field experiments (Morris 1991).

In contrast to effects aboveground, however, belowground live biomass (total roots + rhizomes) was reduced at 12 of 14 fertilized sites, remained the same as in the control at 1 site, and was higher in another 
(Fig. 1). The average belowground biomass was $72 \pm$ $23 \%$ (mean $\pm \mathrm{SD}, \mathrm{n}=14$ ) of the value at the unfertilized control sites. These changes in belowground live biomass in the fertilized plots were greatest when the biomass in the control plots was greatest (Fig. 2). In other words, the environments with the greatest amounts of roots and rhizomes had the greatest change in biomass when fertilizer was added. The

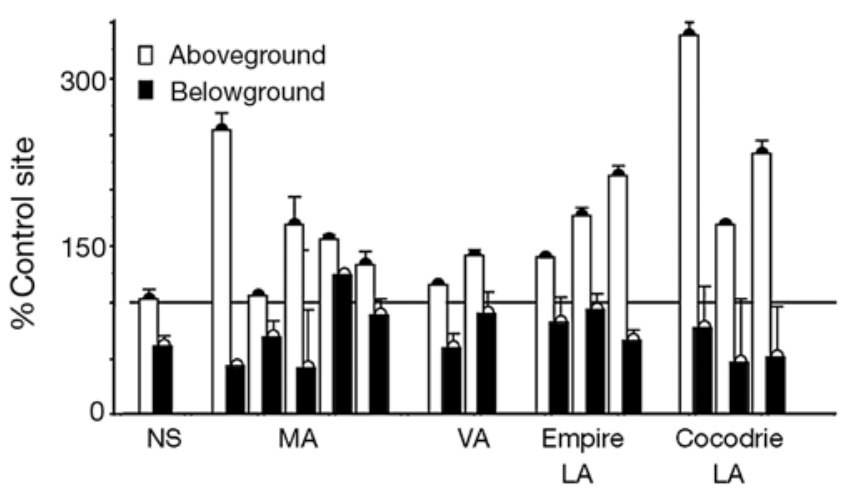

Fig. 1. Spartina alterniflora. Changes in live above- and belowground biomass at the end of the growing season as \% of biomass in replicated fertilized plots relative to the control plots. Nitrogen and phosphorus were added to the surface of the marsh at all sites. NS: Nova Scotia, MA: Massachusetts, VA: Virginia, LA: Louisiana. The 3 left hand bars for Massachusetts are from Valiela et al. (1976). Data are mean (open, closed semicircles, $\pm 1 \mathrm{SE}, \mathrm{n}=14$. Horizontal line indicates no change in biomass

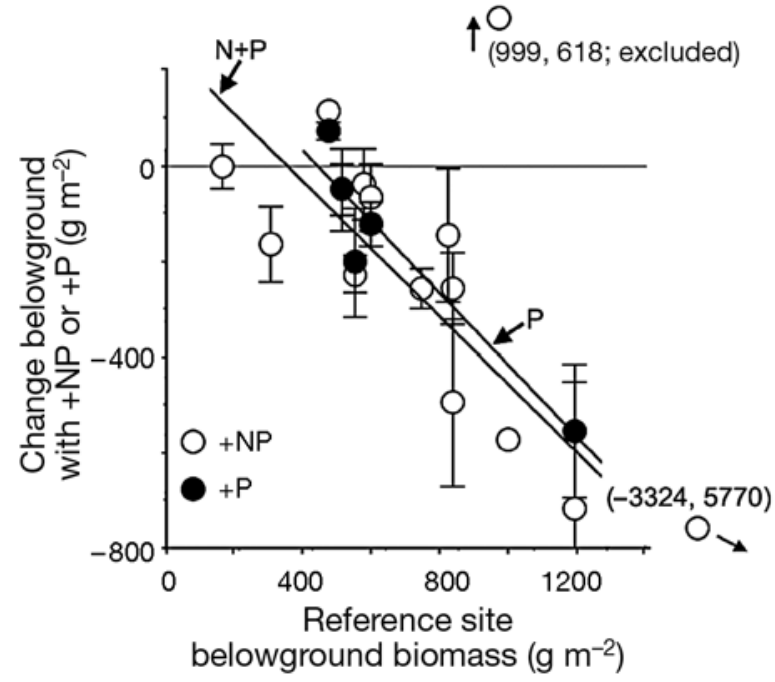

Fig. 2. Spartina alterniflora. Relationship between change in live belowground biomass after several months' fertilization (harvest at the end of the growing season) and live belowground biomass in the reference sites (paired samples). A simple linear regression is shown for the changes in plots with $\mathrm{N}+\mathrm{P}$ and $\mathrm{P}$ only (adjusted $\mathrm{R}^{2}=0.67$ and 0.89 , respectively). Excluded data is from Valiela et al. (1976; upper panel) and Nova Scotia (lower right). Error bars: $\pm 1 \mathrm{SE}$ changes ranged from a $+24 \%$ enhancement of belowground biomass at sites with $<200 \mathrm{~g} \mathrm{~m}^{-2}$ belowground live biomass to a decline of $59 \%$ at sites with the greatest belowground live biomass. There were no differences in the $\mathrm{R}+\mathrm{R}$ biomass between the five sites fertilized with $\mathrm{P}$ only and sites fertilized with $\mathrm{N}+\mathrm{P}$ (pairwise comparison, Fig. 2).

The ratio of live belowground biomass to live aboveground plant biomass (R+R:S) ranged from 0.17:1 to $11: 1(\mathrm{n}=33)$ in western Atlantic marshes, and from 0.05:1 to 15:1 ( $\mathrm{n}=84)$ in Louisiana marshes (GOM). The result of fertilization was to drive the $\mathrm{R}+\mathrm{R}: \mathrm{S}$ ratio lower along the continuum from low to high aboveground standing biomass (Fig. 3). Fertilizer type $(\mathrm{N}, \mathrm{N}+\mathrm{P}, \mathrm{P})$ had an effect on this $\mathrm{R}+\mathrm{R}: \mathrm{S}$ ratio. The $\mathrm{R}+\mathrm{R}: \mathrm{S}$ ratios in plots fertilized with $\mathrm{P}$, or with $\mathrm{P}$ in combination with $\mathrm{N}$ were lower for the same amount of aboveground live biomass than in either unfertilized control plots or plots fertilized with $\mathrm{N}$ only. This disproportionate change in aboveground and belowground live biomass is consistent with the idea that the extent of the decline in $\mathrm{R}+\mathrm{R}: \mathrm{S}$ ratio with increasing aboveground biomass depends on whether or not $\mathrm{P}$ was added to the experimental plots. Regardless of whether $\mathrm{P}$ alone or a combination of $\mathrm{N}$ and $\mathrm{P}$ were added, the $\mathrm{R}+\mathrm{R}: \mathrm{S}$ ratio in fertilized

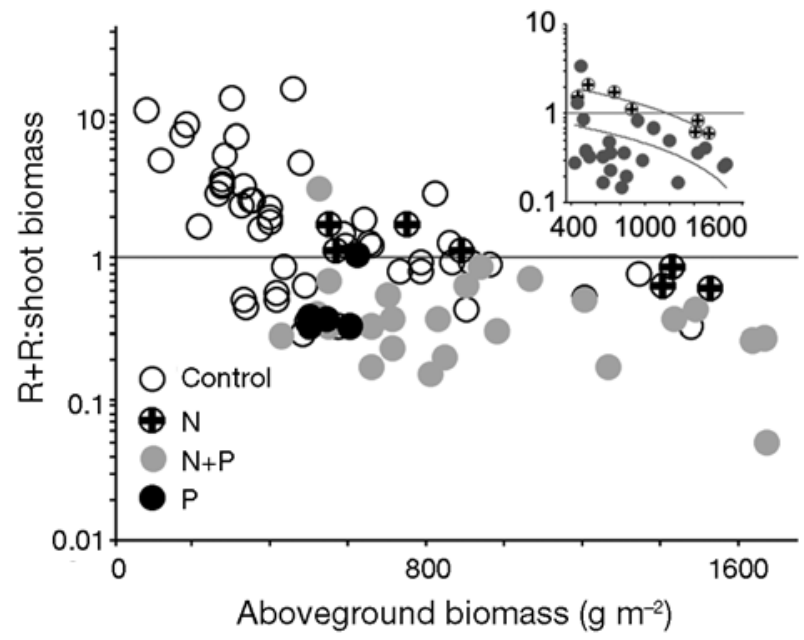

Fig. 3. Spartina alterniflora. Ratio of the belowground live biomass (roots and rhizomes, $\mathrm{R}+\mathrm{R}$ ) to live aboveground biomass in different salt marshes without nutrient additions $(O)$ and with additions of $\mathrm{N}, \mathrm{N}+\mathrm{P}$, or $\mathrm{P}\left(\oplus_{1} \bullet\right.$, and $\bullet$, respectively). Note the log scale on the $y$-axis. Data are from the field sites sampled in this study plus those of Valiela et al. (1976), and cover the end of the growing season. Inset: plot of the same ratio (belowground live biomass to live aboveground biomass) for a subset of the data in which aboveground biomass ranged between 400 and $1700 \mathrm{~g} \mathrm{~m}^{-2}$ (only $\mathrm{N}+\mathrm{P}$ and $\mathrm{N}$ plots have been included). A simple linear regression $\left(\log _{10} y=\right.$ intercept $+\mathrm{g}$ $\mathrm{m}^{-2}$ ) fits of the data is: $y=0.498-0.0005$, adj. $\mathrm{r}^{2}=0.85, \mathrm{p}=$ 0.002 and $y=-0.064-0.0003$, adj. $r^{2}=0.13, p=0.03$ for the $\mathrm{N}$ and $\mathrm{N}+\mathrm{P}$ treatments, respectively 


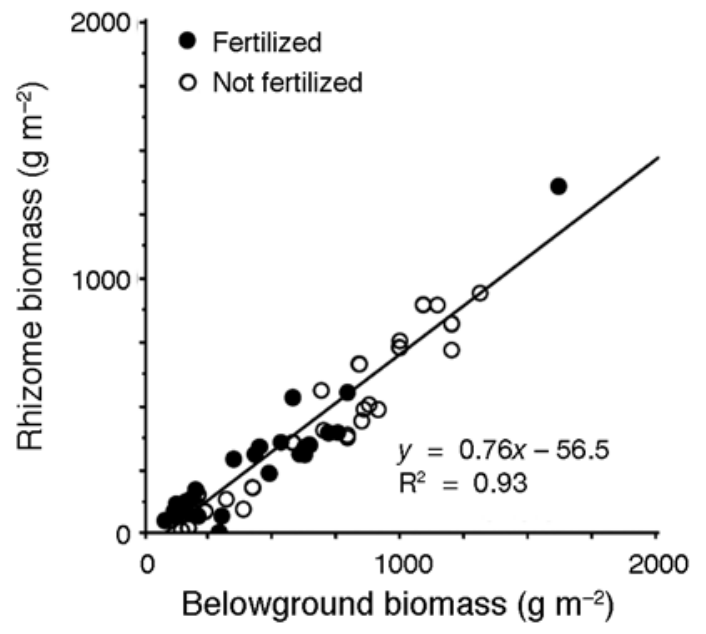

Fig. 4. Spartina alterniflora. Relationship between the biomass of live rhizomes and the total live belowground biomass. Data refer to samples collected at the end of the growing season, as described in the text. Average plot values are shown $(n=77)$. A simple linear regression is fitted to all data points. SEs of plot means ranged from 0 to $55 \%$ percent of standing stock; mean SE $=20 \%$

sites was lower for the same amount of aboveground live biomass than that in unfertilized control plots (Fig. 3 inset).

Rhizomes made up an average $76 \%$ of the end-ofsummer belowground live biomass in the salt marshes sampled (Fig. 4). There was no statistically-significant difference in the proportion of belowground live biomass made up by rhizomes between the fertilized or unfertilized plots, even though the nutrient loading to these sites must have varied widely among western Atlantic and GOM salt marshes. The percent of rhizome production within 'ingrowth' chambers in a New England salt marsh treated with 3 different fertilizer treatments was $80 \%$ of the total $\mathrm{R}+\mathrm{R}$ production (data in Valiela \& Teal 1976, their Table $1 ; \mathrm{r}^{2}=0.80, \mathrm{SE}=8 \%$, $\mathrm{n}=8$ ). The constancy between the biomass of the roots foraging for nutrients and the rhizomes acting as seasonal reserves at the end of the growing season suggests that there were likely no artifacts of fertilization, and supports the idea that these cross-system comparisons are valid.

\section{Soil Eh}

The average soil Eh at $10 \mathrm{~cm}$ depth was directly related to the $\mathrm{R}+\mathrm{R}: \mathrm{S}$ ratio in 12 treatments at Cocodrie, LA (Fig. 5). The average Eh increased as the R+R:S ratio increased. The plots with the highest belowground biomass per unit aboveground biomass had more aerated soil systems.

\section{DISCUSSION}

The field experiments over a wide geographical range demonstrated that the amount of Spartina alterniflora biomass belowground varies disproportionately with changes in aboveground biomass, and that this response is sensitive to both $\mathrm{N}$ and $\mathrm{P}$ loading increases. The paradigm that salt marshes are 'nitrogen limited' aboveground is not challenged by these results because most sites had the same or higher aboveground biomass when $\mathrm{N}+\mathrm{P}$ were added to the plots. The belowground biomass, however, was not responsive to $\mathrm{N}$ treatments alone, but was responsive when supplied in combination with $\mathrm{P}$. The $\mathrm{P}$ treatments alone had the same effect on belowground biomass as $\mathrm{N}+\mathrm{P}$ treatments. The decline in belowground live biomass showed no decreases at a threshold level (about $400 \mathrm{~g} \mathrm{~m}^{-2}$ at the end of the growing season) when $\mathrm{P}$ was added with or without $\mathrm{N}$. The total biomass of $\mathrm{R}+\mathrm{R}$ declined, presumably because foraging for nutrients is more efficient with fertilization; that is, less belowground biomass is needed to absorb nutrients when $\mathrm{P}$ loading increases and fewer belowground reserves are necessary. Nutrient-poor systems, in other words, have the greatest amount of belowground biomass, which reduces with an increase in nutrient availability. The allocation of resources to the above- and belowground parts is dynamically dependent on the quality and quantity

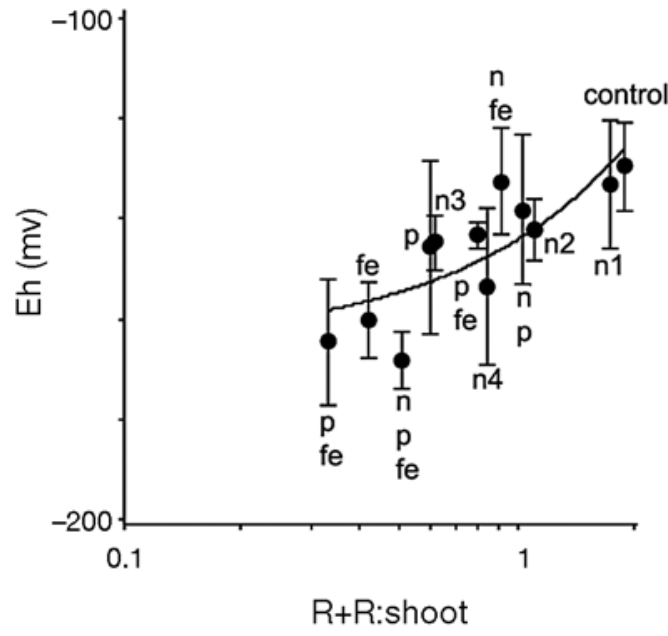

Fig. 5. Spartina alterniflora. Relationship between soil Eh at $10 \mathrm{~cm}$ and the ratio of root and rhizome to shoots (live biomass) in experimental treatments at Cocodrie, Louisiana, 3 September 2004. Note the log scale on the $x$-axis. Data are mean \pm $\mathrm{SE}, \mathrm{n}=3$. The curve is a simple linear regression of the untransformed data $\left(y=-165+20.9 x\right.$; adjusted $r^{2}=0.60, p=$ 0.002). Letters indicate the experimental treatments for the nearest data point (described in Darby \& Turner 2008b): n1 through n5 are increasing loads of nitrogen; p: phosphorus; fe: iron as ironite. The ' $n$ ' with fe or $p$ is the $n 5$ treatment level 
of nutrient availability, but the allometric constancy between rhizome and roots is relatively stable.

The R+R:S ratio and the soil redox potential decreased when either N or P loading increased. Soil Eh may decline at these sites because of greater respiratory demand, but not from increased flooding, because the control and fertilized sites were located within $10 \mathrm{~m}$ of each other in a marsh that appeared homogenous. Soil respiration has been shown to increase with higher nutrient loading, e.g. in an inorganic-rich South Carolina (USA) salt marsh dominated by Spartina alternifora (Morris \& Bradley 1999) and in an organic-rich soil within the $S$. patens zone in Rhode Island (Caffrey et al. 2007). Harris et al. (1962) found that nitrogen amendments to drained histosols increased soil subsidence, presumably because of increased soil carbon oxidation. A consequence of the lowered Eh profile might be the catastrophic demise of vegetation (Mendelssohn et al. 1981), something that can reduce the soil profile by $15 \mathrm{~cm}$ within a growing season (DeLaune et al. 1994). Our results may appear, however, to be inconsistent with the observations of King et al. (1982), but they are not. King et al. (1982) observed that dissolved sulfide concentrations in a Georgia $S$. alterniflora marsh were negatively correlated with above-ground production. Their data were from comparisons among marsh types that had different hydrologic regimes (streamside and inland marshes), whereas the data shown in Fig. 5 are from one marsh with relatively small variations in tidal flushing (and iron supply).

Soil metabolism might increase with nutrient loading because denitrification uses carbon as an electron donor, leading to the diminished carbon pool described by Morris \& Bradley (1999). Oxygen supply may decrease with either reduced root mass, or because of changes in the aerenchyma tissue that transports gas from above- to belowground parts. The indications are (based on the results shown in Figs. 1 to 4) that belowground carbon production is inversely related to nutrient loading. This arises from the decline in belowground standing stock with higher nutrient loading and because production:standing stock ratios (P:SS ratios, based on the annual production and the end-of-season standing stock of live material) are directly related to standing stock (Darby \& Turner 2008a). If nutrient additions lead to a lower carbon production belowground, then soil microbial metabolism must be more active, as found by Morris \& Bradley (1999) for a South Carolina marsh. Further, Spartina alterniflora salt marsh soils contain a Plimited soil microbial community (Sundareshwar et al. 2003) whose metabolism should become more active with increasing $P$. The result is that soil carbon can be depleted because less organic matter is produced, and because a higher proportion of production is metabolized. Further speculations about the aerobic or anerobic metabolic pathways favored by fertilization await detailed field-based data collected over several years.

The effects of higher nutrient loading to salt marshes will not be equally distributed across the salt marsh landscape. The amount of belowground plant biomass found among locations reflects the relative ease with which plants extract nutrients from the soil and move them to the aboveground biomass, but is also dependent on many other influences. Nutrients loaded to a wetland do not necessarily become available to the plant because of factors limiting in situ soil processes, e.g. redox reactions transforming nitrogen from one available form to another, the presence/absence of toxins such as sulfides, and immobilization (iron phosphates) (Howes et al. 1981, 1985). It is at these limits that new stressors, or the multiple effects of existing stressors, will probably most affect the salt marsh ecosystem.

Where are the salt marshes most likely to experience a decline in soil volume because of higher nutrient loading? Compared to salt marshes with organic soils, the accumulation of mineral soils will not be affected very much by reduction in belowground biomass resulting from eutrophication because either the volume occupied by the mineral matter is high, or because the increased stem density will trap more sediments to compensate for the volume lost by a diminished organic carbon content. Two examples of mineral soils are the relatively inorganic-rich South Carolina marshes studied by Morris \& Bradley (1999) and the marshes in the Bay of Fundy, Canada. Soil volumes in the Great Sippewissett marshes (MA) may not lose much more volume through effects of further eutrophication on $\mathrm{R}+\mathrm{R}$ biomass, because $\mathrm{R}+\mathrm{R}$ biomass there is relatively low (about $300 \mathrm{~g} \mathrm{~m}^{-2}$, Fig. 2).

Soil volumes will change the most in response to nutrient additions where soil organic content and $\mathrm{R}+\mathrm{R}$ production are high, and where organic decomposition rates are relatively low, viz. in warm climates, where there are organic soils, and in 'pristine' estuaries. The highest belowground production rates per unit belowground biomass occurred in the sub-tropical GOM salt marshes. The accretion rates of the inter-levée deltaic marshes are almost completely dependent on soil organic accumulations. One gram of organic matter there, for example, is volumetrically equivalent to $22 \mathrm{~g}$ of inorganic matter (Turner et al. 2000).

Although the effect of fertilization is to reduce the standing stock of belowground plant biomass at the end of the growing season (Figs. 1,2), the effect of a changing standing stock on the total below- or aboveground biomass production depends on the level 
of biomass production per unit standing biomass throughout the year. The production:standing stock ratio (P:SS) was highest in Louisiana and lowest in Atlantic coast marshes (Darby \& Turner 2008a). The effect of nutrient additions to these organic marshes is, therefore, expected to be more important than in marshes with a high inorganic content.

Nutrient additions result in a disproportionate change in the P:SS ratios above- and belowground, leading to lower $\mathrm{R}+\mathrm{R}: \mathrm{S}$ ratios. Under the right conditions, the addition of nutrients may result in less total plant production. For example, Louisiana marshes have an end-of-season (EOS) aboveground P:SS ratio of 2.25:1 (Kaswadji et al. 1990), and the aboveground biomass may double with nutrient additions. The belowground biomass in these same marshes declines by about $50 \%$ with nutrient additions, and the belowground EOS P:SS ratio is ca. 10:1, which is about 4 -fold higher than that of the aboveground biomass (Darby \& Turner 2008b). The cumulative effect of nutrient additions in these Louisiana salt marshes may (somewhat paradoxically) be a lowering of total salt marsh plant production, rather than an enhancement.

These results have two potential implications for coastal wetland conservation. More plant production aboveground may be expected to result in less belowground production, which is not a desirable management goal for organic-rich coastal marshes dependent on belowground organics to maintain their vertical position with rising sea levels. The reduction in roots and rhizomes may contribute to sudden salt marsh dieback, especially in nutrient-rich urban areas (e.g. Jamaica Bay, New York, USA; Hartig et al. 2002). Another consequence is that a diminished root mat has reduced ability to resist erosion and storm events. Restoration monitoring valuations based on higher aboveground plant biomass, therefore, may be fatally flawed were they to place a higher value on increased aboveground biomass rather than belowground biomass or plant cover. It appears that reducing the loadings of $\mathrm{N}$ and $\mathrm{P}$ to coastal systems will simultaneously favor coastal wetland conservation and be consistent with other goals of water quality improvement programs.

Acknowledgements. We thank J. Baustian, J. Lee, C. Milan, T. Oswald, J. Spicer and E. Swenson for assistance in the field sampling, and L. Blum, B. Howes, D. Toner and staff for logistical support and field assistance when sampling Virginia and Massachusetts salt marshes. We thank 3 anonymous reviewers who made comments that contributed towards an improved manuscript. Support was provided by the NOAA Coastal Ocean Program MULTISTRESS Award No. NA16OP2670 to Louisiana State University and a Louisiana Board of Regents Fellowship to F.A.D.

\section{LITERATURE CITED}

Alastair F (2002) Characteristics and function of root systems. In: Waisel Y, Eshel A, Kafkafi U (eds) Plant roots: the hidden half. Marcel Dekker, New York, p 15-32

Bertness MD, Ewanchuk PJ, Silliman BR (2002) Anthropogenic modification of New England salt marsh landscapes. Proc Natl Acad Sci USA 99:1395-1398

Blum LK (1993) Spartina alterniflora root dynamics in a Virginia marsh. Mar Ecol Prog Ser 102:169-178

Blum LK, Christian RR (2005) Belowground production and decomposition along a tidal gradient in a Virginia salt marsh. In: Fagherazzi S, Marani M, Blum LK (eds) The ecomorphology of tidal marshes. American Geophysical Union, Washington, DC, p 47-74

Caffrey JM, Murrell MC, Wigand C, McKinney R (2007) Effect of nutrient loading on biogeochemical and microbial processes in a New England salt marsh. Biogeochemistry $82: 251-264$

> Chapin FS (1980) The mineral nutrition of wild plants. Annu Rev Ecol Syst 11:233-260

> Cloern JE (2001) Our evolving conceptual model of the coastal eutrophication problem. Mar Ecol Prog Ser 210: 223-253

Daborn GR, Brylinsky M, van Proosdji D (2003) Ecological Studies of the Windsor Causeway and Pescaquid Lake, 2002. Acadia Centre for Estuarine Research Publ. 69, Acadia University, Wolfville

Darby FA, Turner RE (in press) (2008a) Below- and aboveground Spartina alterniflora production in a Louisiana salt marsh. Estuaries Coast 31:223-231

Darby FA, Turner RE (in press) (2008b) Below- and aboveground biomass of Spartina alterniflora production: response to nutrient addition in a Louisiana salt marsh. Estuaries Coast 31:326-334

DeLaune RD, Nyman JA, Patrick WH Jr (1994) Peat collapse, ponding and wetland loss in a rapidly submerging coastal marsh. J Coast Res 10:1021-1030

> Gedroc JJ, McConnaughay KDM, Coleman JS (1996) Plasticity in root/shoot partitioning: optimal, ontogenetic, or both? Funct Ecol 10:44-50

Gill RA, Jackson RB (2000) Global patterns of root turnover for terrestrial ecosystems. New Phytol 147:13-31

Gosselink JG, Hatton R, Hopkinson CS (1984) Relationship of organic carbon and mineral content to bulk density in Louisiana marsh soils. Soil Sci 137:177-180

Harris CI, Erickson HT, Ellis NK, Larson JE (1962) Water-level control in organic soil, as related to subsidence rate, crop yield, and response to nitrogen. Soil Sci 94:158-161

Hartig EK, Gornitz V, Kolker A, Muskacke F, Fallon D (2002) Anthropogenic and climate-change impacts on salt marshes of Jamaica Bay, New York city. Wetlands 22: 71-89

Howarth RW, Marino R (2006) Nitrogen as the limiting nutrient for eutrophication in coastal marine ecosystems: evolving views over three decades. Limnol Oceanogr 51: 364-376

Howes BL, Howarth RW, Teal JM, Valiela I (1981) Oxidationreduction potentials in a salt marsh: spatial patterns and interactions with primary production. Limnol Oceanogr $26: 350-360$

Howes BL, Dacey JWH, Teal JM (1985) Annual carbon mineralization and belowground production of Spartina alterniflora in a New England salt marsh. Ecology 66:595-596

Huang X, Morris JT (2005) Distribution of phosphatase activity in marsh sediments along an estuarine salinity gradient. Mar Ecol Prog Ser 292:75-83 
Kaswadji R, Gosselink JG, Turner RE (1990) Estimation of primary production using five different methods in a Spartina alterniflora salt marsh. Wetlands Ecol Manage 1:57-64

King GM, Klug MJ, Wiegert RG, Chalmers AG (1982) Relation of soil water movement and sulfide concentration to Spartina alterniflora productivity in a Georgia salt marsh. Science 218:61-63

Mendelssohn IA (1979) The influences of nitrogen level, form, and application method on the growth response of Spartina alterniflora in North Carolina. Estuaries 2:106-112

Mendelssohn IA, McKee KL, Patrick WH Jr (1981) Oxygen deficiency in Spartina alterniflora roots: metabolic adaptation to anoxia. Science 214:439-441

Morris JT (1991) Effects of nitrogen loading on wetland ecosystems with particular reference to atmospheric deposition. Annu Rev Ecol Syst 22:257-279

Morris JT, Bradley P (1999) Effects of nutrient loading on the carbon balance of coastal wetland environments. Limnol Oceanogr 44:699-702

National Research Council (2000). Clean coastal waters. Understanding and reducing the effects of nutrient pollution. National Academies Press, Washington, DC

Rabalais NN (2002) Nitrogen in aquatic ecosystems. Ambio 31:102-112

Rooth JE, Stevenson JC (2000) Sediment deposition patterns in Phragmites australis communities: implications for coastal areas threatened by rising sea-level. Wetlands Ecol Manag 8:173-18

SAS Institute (2003) Version 9.1. Cary, NC

Editorial responsibility: Robert Feller,

Columbia, South Carolina, USA
Schuhauer JP, Hopkinson CS (1984) Above- and belowground emergent macrophyte production and turnover in a coastal marsh ecosystem, Georgia. Limnol Oceanogr 29: $1052-1063$

Spicer J (2007) A comparison of channel morphology, marsh elevation and biological processes in natural and dredged tidal marshes in Louisiana. PhD dissertation, Louisiana State University, Baton Rouge, LA

Sundareshwar PV, Morris JT, Koepfler EK, Formwalt B (2003) Phosphorus limitation of coastal ecosystem processes. Science 299:563-565

Tilman D, Wedin D (1991) Plant traits and resource reduction for five grasses growing on a nitrogen gradient. Ecology 72:685-700

Turner RE, Rabalais NN (1999) Suspended particulate and dissolved nutrient loadings to Gulf of Mexico estuaries. In: Bianchi TS, Pennock JR, Twilley RW (eds) Biogeochemistry of Gulf of Mexico estuaries. J. Wiley \& Sons, Hoboken, NJ, p 89-107

Turner RE, Swenson EM, Milan CS (2000) Organic and inorganic contributions to vertical accretion in salt marsh sediments. In: Weinstein M, Kreeger K (eds) Concepts and controversies in tidal marsh ecology. Kluwer Academic Publishing, Dordrecht, p 583-595

Turner RE, Swenson EM, Milan CS, Lee JM, Oswald TA (2004) Belowground biomass in healthy and impaired salt marshes. Ecol Res 19:29-35

Valiela I, Teal JM, Persson NY (1976) Production dynamics of experimentally enriched salt marsh vegetation: belowground biomass. Limnol Oceanogr 21:245-252

Submitted: July 5, 2007; Accepted: January 25, 2008

Proofs received from author(s): June 16, 2008 